\title{
Case Report: Acute pancreatitis as a complication for the use \\ of furosemide during transurethral resection of the prostate
}

\section{[version 1; peer review: 2 not approved]}

\author{
J. Antonio Grandez-Urbina (iD1, Anggie Santillan-Romero², \\ Mariela Corrales-Acosta², J. Eduardo Tejeda-Mariaca ${ }^{3,4}$, \\ J. Luis Fernandez-Luque (iD) 2,5 \\ ${ }^{1}$ Universidad Continental, Miraflores, Lima, 15046, Peru \\ ${ }^{2}$ Biomedical Research Institute, Universidad Ricardo Palma, Santiago de Surco, Lima, 15039, Peru \\ 3Urology Department, Hospital Nacional Alberto Sabogal Sologuren, Bellavista, Callao, 07011, Peru \\ 4Uroscience Research Group, Lima, 15046, Peru \\ ${ }^{5}$ Research Unit, Lima del Mar Medical Center, Lima, Peru
}

V1 First published: $03 \operatorname{Dec} 2019, \mathbf{8 : 2 0 5 1}$

https://doi.org/10.12688/f1000research.21144.1

Latest published: 03 Dec 2019, 8:2051

https://doi.org/10.12688/f1000research.21144.1

\section{Abstract}

Background: Pancreatitis caused after transurethral resection of the prostate (TURP) is an uncommon complication, with few reports found in the literature. Here we present the case of a middle-aged patient without comorbidities with this pathology.

Clinical case: A 66-year-old male patient with no prior medical history underwent TURP surgery due to benign prostatic hyperplasia. The evolution was unfavourable, leading to post TURP syndrome. On the fifth day after surgery, the patient was admitted for emergency dialysis. During his emergency stay, the patient was unstable; he was diagnosed with pancreatitis, moving to an intensive care unit for management The patient progressed favourably from renal failure and pancreatitis, and on the 5th day the patient was discharged, tolerating oral feeding and stabilized renal failure.

Conclusions: Pancreatitis caused by TURP is very rare. This complication has been reported in the literature infrequently and should be suspected when there is pain in the epigastrium. If this complication is suspected, imaging tests and pancreatic enzyme levels should be immediately requested, as it can have an unfavourable evolution until death.

\section{Keywords}

Furosemide, pancreatitis, Transurethral Resection of Prostate, DrugRelated Side Effects and Adverse Reactions

\section{Open Peer Review Approval Status $\mathrm{X} \times$ \\ 1 2 \\ version 1 \\ 03 Dec 2019

$\underset{\text { view }}{\boldsymbol{X}}$ \\ 1. Hemendra N Shah iD, Miller School of Medicine, University of Miami, Miami, USA \\ 2. Hrishi Joshi ID, University Hospital of Wales, Cardiff, UK \\ Thomas Minto iD, University Hospital of \\ Wales, Cardiff, UK \\ Any reports and responses or comments on the article can be found at the end of the article.}


Corresponding author: J. Antonio Grandez-Urbina (jagrandez@gmail.com)

Author roles: Grandez-Urbina JA: Conceptualization, Project Administration, Writing - Original Draft Preparation, Writing - Review \& Editing; Santillan-Romero A: Conceptualization, Writing - Original Draft Preparation, Writing - Review \& Editing; Corrales-Acosta M: Conceptualization, Writing - Original Draft Preparation, Writing - Review \& Editing; Tejeda-Mariaca JE: Conceptualization, Writing Original Draft Preparation, Writing - Review \& Editing; Fernandez-Luque JL: Conceptualization, Writing - Original Draft Preparation, Writing - Review \& Editing

Competing interests: No competing interests were disclosed.

Grant information: The author(s) declared that no grants were involved in supporting this work.

Copyright: ( 2019 Grandez-Urbina JA et al. This is an open access article distributed under the terms of the Creative Commons Attribution License, which permits unrestricted use, distribution, and reproduction in any medium, provided the original work is properly cited.

How to cite this article: Grandez-Urbina JA, Santillan-Romero A, Corrales-Acosta $\mathrm{M}$ et al. Case Report: Acute pancreatitis as a complication for the use of furosemide during transurethral resection of the prostate [version 1; peer review: 2 not approved] F1000Research 2019, 8:2051 https://doi.org/10.12688/f1000research.21144.1

First published: 03 Dec 2019, 8:2051 https://doi.org/10.12688/f1000research.21144.1 


\section{Introduction}

Acute pancreatitis caused after transurethral resection of the prostate (TURP) is an uncommon complication, with few reports found in the literature. It usually occurs in those who develop TURP syndrome ${ }^{1}$.

The prognosis depends on suspicion of this complication in a timely manner because it lead to multi-organ failure and even death ${ }^{1}$.

The case presented herein describes the case of a middleaged patient who develops pancreatitis after TURP. The report describes how this was managed, the treatment used, and a review of the literature to identify similar cases.

\section{Clinical case}

A timeline of the patient's case can be seen in Figure 1.

\section{Patient information}

A 66-year-old male with a prior history of high blood pressure (treatment, Valsartan $80 \mathrm{mg}$ bid), without any prior history of alcoholism, previous pancreatitis episodes, or gallbladder disease underwent TURP surgery after diagnosis with obstructive benign prostatic hyperplasia (BPH). This was detected with an approximate weight of 45 gr by ultrasound and a verumneck distance of $3 \mathrm{~cm}$ in cystoscopy. The patient had no family history of hypertriglyceridemia or gallbladder stones.

Monopolar TURP surgery was performed using 13 liters of distilled water for continuous bladder irrigation. During surgery, $80 \mathrm{mg}$ of furosemide $\mathrm{EV}$ was used to reduce the risk of dilutional hyponatremia. The operative time was 55 minutes, removing $17 \mathrm{gr}$ of prostate tissue; with no intraoperative complications. No lesion of the capsule or any significant bleeding was reported.

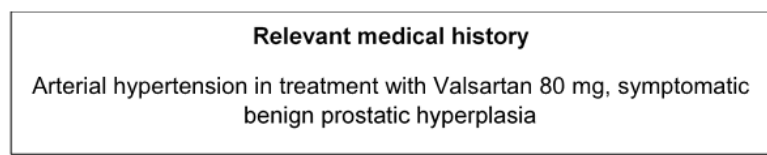

\begin{tabular}{|c|}
\hline $\begin{array}{l}\text { Current illness } \\
\text { Transurethral resection of monopolar } \\
\text { prostate is performed, } 80 \mathrm{mg} \text { of furosemide } \\
\text { is used during surgery. }\end{array}$ \\
\hline $\begin{array}{l}\text { Physical exam } \\
\text { Oral intolerance, diffuse pain radiated in the } \\
\text { belt. Abdomen distended painful to palpation } \\
\text { in mesogastrium. }\end{array}$ \\
\hline $\begin{array}{c}\text { Auxiliary tests for diagnosis } \\
\text { Performed Abdomino Pelvic Multislice } \\
\text { Tomography, increased density of peri- } \\
\text { pancreatic fat with little free liquid. Azoados } \\
(\mathrm{Cr}=12.43 \mathrm{mg} / \mathrm{dl} \text { and Urea }=235 \mathrm{mg} / \mathrm{dl}) \text {. } \\
\text { Amylase }=329 \mathrm{U} / \mathrm{L}(\mathrm{VN}:<105), \text { Lipase }= \\
304 \mathrm{U} / \mathrm{L}(\mathrm{VN}:<50) \text { and leukocytes: } 20880 \\
\mathrm{ml} / \mathrm{mm} 3 .\end{array}$ \\
\hline $\begin{array}{c}\text { Diagnosis } \\
\text { Post pTRP acute pancreatitis }\end{array}$ \\
\hline
\end{tabular}

Episode resolution

Figure 1. Timeline of the important points in the patient's medical history, interventions and follow-up. 


\section{Clinical findings}

After surgery, a physical abdominal and genitourinary exploration was carried out. There was evidence of oral intolerance, abdominal distention and increased abdominal resistance, with pain at the epigastrium that radiated to the lumbar region. Permeable Foley catheter with clear urine was reported.

\section{Diagnostic assessment}

At 24 hours post-surgery, the patient presented elevation of azoles $(\mathrm{Cr}=3.7 \mathrm{mg} / \mathrm{dl}$; Urea $=92 \mathrm{mg} / \mathrm{dl})$ and oliguria, therefore furosemide $20 \mathrm{mg}$ was administered twice a day. After 72 hours of follow-up, the condition persisted, and it was decided to increase treatment with furosemide to $20 \mathrm{mg} \mathrm{EV}$ three times a day; despite this, it evolves in an unfavourable manner. On the fifth day after surgery, elevation azoles continued $(\mathrm{Cr}=12.43 \mathrm{mg} / \mathrm{dl}$; Urea $=235 \mathrm{mg} / \mathrm{dl})$, and there was also an increase in pancreatic enzymes (Amylase $=329 \mathrm{U} / \mathrm{L}$ (Normal value $<105)$; Lipase $=304 \mathrm{U} / \mathrm{L}($ Normal value: $<50)$; leukocytes $=20880 \mathrm{ml} / \mathrm{mm} 3($ Normal value $=4500 \mathrm{ml} / \mathrm{mm} 3$ to $10500 \mathrm{ml} / \mathrm{mm} 3)$. The aggregate infectious process was improved. An abdominal-pelvic CT scan was performed, finding a slight increase in the density of peripancreatic mesenteric fat with the presence of low laminar free fluid (Figure 2). The patient was transferred to the Intensive Care Unit (ICU) for emergency dialysis and stabilization.

\section{Therapeutic interventions}

Three sessions of haemodialysis and treatment of pancreatitis were required to stabilize the condition. On the fourth day of admission to the ICU, the patient progressed favourably from renal failure and pancreatitis by reduction in levels of pancreatic enzymes and creatinine, and on the 5th day the patient was discharged, tolerating oral feeding and stabilized renal failure.

\section{Follow-up and outcomes}

Amoxicillin/clavulanic acid 500mg three times a day was prescribed for five days. The Foley catheter was removed on

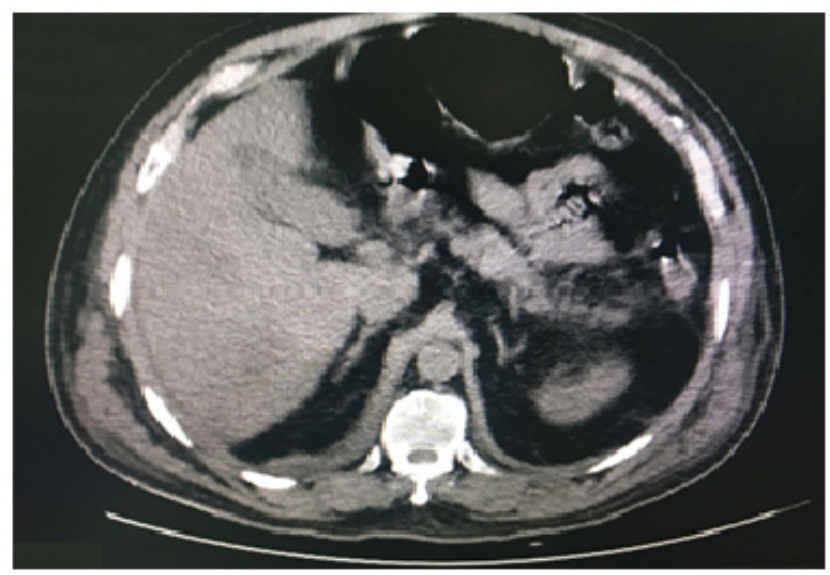

Figure 2. Abdominopelvic CT scan. Pancreas is not increased in size, no pancreatic necrosis, no peripancreatic collections. Slight increase in the density of mesenteric fat. Presence of low laminar free liquid. the fifth day after surgery as it was not necessary to monitor urine volume. Renal impairment was progressively restored, and the level of creatinine three months after surgery was $0.98 \mathrm{mg} / \mathrm{dl}$. No urethral stricture or any other urinary complications were reported.

\section{Discussion}

Acute pancreatitis is an inflammatory disease of the pancreas that can also involve neighbouring tissues or organs, with a highly variable clinical presentation. In some cases, it has significant morbidity and mortality ${ }^{1,2} ; 20 \%$ of patients adopt a severe evolutionary course, with persistent organ failure leading to mortality in $25 \%$. The reported age range is between 50 and 75 years, as the incidence of acute pancreatitis increases with age $^{1,2}$.

Approximately $80-90 \%$ of cases are due to alcohol consumption and gallbladder lithiasis, while $10-20 \%$ have variable aetiology, including idiopathic, hyperlipaemias, viral infections, impaired pancreatic perfusion, ductal obstructions, drugs, and hypercalcemia ${ }^{3,4}$.

Drug-associated pancreatitis is an underreported entity with an incidence of 0.1 to $2 \%$. Drugs that have been associated with causing pancreatitis that have been reported in the literature include antihypertensive agents, proton pump inhibitors, anticonvulsants, and chemotherapeutic agents ${ }^{5}$.

Lesions in the pancreatic tissue is caused by aggressor factors (drugs, infection, or metabolic disorder) and by the secondary activation of digestive zymogens within acinar cells, which trigger a subsequent inflammatory response ${ }^{3}$. The mechanisms by which these complications develop are not fully understood, but intestinal endotoxins and inflammatory mediators play an important role ${ }^{1}$.

The diagnosis of drug-associated pancreatitis is by exclusion, so it is recommended to use the "Naranjo Scale of drug adverse reaction probability" in order to calculate the probability of adverse drug effect (Table 1). In 1981 Naranjo et al. validated this scale for cases of adverse drug reactions. In our case, the total score of our patient was 5 (answered affirmatively in questions $1,2,3$ and 10), classified as probable in relation to furosemide ${ }^{6}$.

Drugs such as furosemide have been described that could damage pancreatic perfusion by decreasing intravascular volume, affecting blood flow, producing ischemia and the subsequent development of acute pancreatitis. It may also stimulate the exocrine pancreas producing a hypersensitivity reaction ${ }^{1,6,7}$.

In our patient, Valsartan was suspected of having contributed to the presentation. However, due to the prolonged exposure time, it was dismissed as a possible aetiology.

In the literature, risk factors associated with drug pancreatitis have been described, of which our patient presented advanced age and vascular risk factors. As a result of these factors an 
Table 1. Naranjo scale of drug adverse reaction probability.

\begin{tabular}{|c|c|c|c|}
\hline Naranjo scale of drug adverse reaction probability & YES & NO & NK \\
\hline Are there conclusive notifications about this reaction? & +1 & 0 & 0 \\
\hline Did adverse reaction occur after administering the suspect drug? & 2 & -1 & 0 \\
\hline Did AR improve after stopping drug administration or after administering a specific antagonist? & 1 & 0 & 0 \\
\hline Did AR improve after stopping drug administration or after administering a specific antagonist? & 2 & -1 & 0 \\
\hline Are there alternative causes (other than the drug) that could have caused the reaction itself? & -1 & 2 & 0 \\
\hline Did AR reappear after administering placebo & -1 & 1 & 0 \\
\hline Was the drug detected in the blood (or other fluids) in toxic concentrations? & 1 & 0 & 0 \\
\hline Was the reaction more severe when increasing the dose or less severe when decreasing it? & 1 & 0 & 0 \\
\hline Did the patient have a similar reaction caused by the same or similar drug in any previous exposure? & 1 & 0 & 0 \\
\hline Was the adverse event confirmed by any type of evidence of objective evidence? & 1 & 0 & 0 \\
\hline
\end{tabular}

Total score is the sum of the subcategories. The relationship is categorized as Definitive if the score is> 8; likely if it is between 5 - 8 ; possible if it is between $1-4$; and doubtful if the score is 0

increase in pancreatic toxicity may have occurred, due to atherosclerosis of mesenteric vessels, resulting in furosemide making the perfusion worse by diuresis and intravascular volume depletion $^{8}$. However, the exact mechanism is not yet known. However, some hypotheses include that furosemide could stimulate exocrine secretion of the pancreas, or mechanisms of hypersensitivity or immune response against a drug-protein. As evidenced in multiple reports, there are many confounding factors, but they only increase pancreatic susceptibility. In our case, the precipitating event is the administration of furosemide.

The present patient did not present capsule perforation or postsurgery bleeding. Berber-Deseusaa et al. present the case of a patient who presents capsule perforation during the intraoperative period $^{1}$. In our case, pancreatitis was mild, presenting improvement on the eighth post-surgery day after dialysis. However, the case reported by Berber-Deseusaa et al. presented severe necrotizing pancreatitis, leading to the death of the patient ${ }^{1}$.

Acute pancreatitis is an infrequent complication reported after TURP ${ }^{1,9-11}$; it can delay diagnosis if it is not considered as a possibility ${ }^{1}$. In our patient, the surgery was without complication, unlike previous cases presented in the literature where capsule perforation was observed ${ }^{1}$. The present surgical time was 55 minutes.

On the other hand, the evolution of our patient was favourable in contrast to what was presented by Berber et al., where the two patients presented unfavourable evolution with acute renal failure, ventilatory-circulatory deterioration, and death ${ }^{1}$.

\section{Conclusions}

The clinical features of pancreatitis following TURP surgery has been reported previously in the literature but infrequently. This condition should be suspected when dealing with pain in the epigastrium post TURP. If this complication is suspected, imaging tests and pancreatic enzyme levels should be immediately requested, as it can have an unfavourable evolution until death.

\section{Data availability}

All data underlying the results are available as part of the article and no additional source data are required.

\section{Consent}

Written informed consent for publication of their clinical details and clinical images was obtained from the patient.
1. Berber-Deseusaa A, Rosas-Navaa JE, de los Santos-Gonzáleza J, et al.: Pancreatitis posterior a resección transuretral de próstata. Publisher Full Text

2. Sánchez AC, Aranda G, Alberto J: Pancreatitis aguda. Bol Méd Hosp Infant México. 2012; 69(1): 3-10. Reference Source

3. Breijo Puentes A: Pancreatitis aguda. Artículo de revisión. IntraMed J [Internet]. 2014 [citado 1 de abril de 2018]; 3(2).

Reference Source
4. Vege SS, Gardner TB, Chari ST, et al.: Low mortality and high morbidity in severe acute pancreatitis without organ failure: a case for revising the Atlanta classification to include "moderately severe acute pancreatitis". Am J Gastroenterol. 2009; 104(3): 710-5. PubMed Abstract | Publisher Full Text

5. Badalov N, Baradarian R, Iswara K, et al.: Drug-induced acute pancreatitis: an evidence-based review. Clin Gastroenterol Hepatol. 2007; 5(6): 648-61; quiz 644. PubMed Abstract | Publisher Full Text

6. Naranjo CA, Busto U, Sellers EM, et al:: A method for estimating the probability 
of adverse drug reactions. Clin Pharmacol Ther. 1981; 30(2): 239-45. PubMed Abstract | Publisher Full Text

7. Kaurich T: Drug-induced acute pancreatitis. Proc Bayl Univ Med Cent. 2008;

21(1): 77-81.
PubMed Abstract | Publisher Full Text | Free Full Text

8. Chao C-T, Chao J-Y: Case report: furosemide and pancreatitis: Importance of dose and latency period before reaction. Can Fam Physician. 2013; 59(1): 43-5. PubMed Abstract | Free Full Text

9. Levine SR, Gambill EE, Greene LF: Acute pancreatitis following transurethral prostatic resection: report of six cases. J Urol. 1962; 88: 657-63. PubMed Abstract | Publisher Full Text

10. Nicholls AJ, Catto GR: Acute pancreatitis and acute tubular necrosis following transurethral resection of the prostate. Br J Clin Pract. 1981; 35(6) 235-7.

PubMed Abstract

11. Lee MH, Chen KK, Lin AT, et al:: Acute pancreatitis following transurethral resection of prostate. Eur Urol. 1993; 23(3): 419-22. PubMed Abstract | Publisher Full Text 


\title{
Open Peer Review
}

\section{Current Peer Review Status: $\mathrm{X} \times$}

\section{Version 1}

Reviewer Report 05 March 2021

https://doi.org/10.5256/f1000research.23275.r78703

(C) 2021 Joshi $\mathbf{H}$ et al. This is an open access peer review report distributed under the terms of the Creative Commons Attribution License, which permits unrestricted use, distribution, and reproduction in any medium, provided the original work is properly cited.

\author{
Hrishi Joshi \\ Department of Urology, University Hospital of Wales, Cardiff, UK \\ Thomas Minto \\ Department of Urology, University Hospital of Wales, Cardiff, UK
}

The authors introduce a case of acute pancreatitis requiring intensive care support. The initial causation is argued to be the surgical procedure (transurethral resection of the prostate), however, it becomes conflicted with the arbitrary use of furosemide peri-procedure without presented rationale.

The clinical diagnosis of pancreatitis isn't wholly convincing with borderline enzyme levels which in other countries of the world is only just diagnostic.

There is no information regarding prior patient details regarding BPE and trials of medical management. Procedure details are also not consistent with normal global practice including the use of distilled water as the irrigation fluid and use of loop diuretic both peri-procedure and postprocedure.

The leap to conclude that the operation is the cause of the pancreatitis isn't explained with any substantial supporting evidence and there are a plethora of alternative diagnoses equally as likely. There is little relevance to the practicing urologist from this case.

Is the background of the case's history and progression described in sufficient detail? No

Are enough details provided of any physical examination and diagnostic tests, treatment given and outcomes?

No

Is sufficient discussion included of the importance of the findings and their relevance to future understanding of disease processes, diagnosis or treatment? No

Is the case presented with sufficient detail to be useful for other practitioners? 
No

Competing Interests: No competing interests were disclosed.

Reviewer Expertise: Urology

We confirm that we have read this submission and believe that we have an appropriate level of expertise to state that we do not consider it to be of an acceptable scientific standard, for reasons outlined above.

Reviewer Report 15 February 2021

https://doi.org/10.5256/f1000research.23275.r78702

(C) 2021 Shah H. This is an open access peer review report distributed under the terms of the Creative Commons Attribution License, which permits unrestricted use, distribution, and reproduction in any medium, provided the original work is properly cited.

\section{Hemendra N Shah}

Department of Urology, Miller School of Medicine, University of Miami, Miami, Florida, USA

The authors present a case report of mild pancreatitis that was diagnosed 5 days after TURP. Valuable information about the indication for TURP, patients PSA level, the trial of medical management for $\mathrm{BPH}$, associated medical conditions is missing.

There is no description of the possible cause of postoperative Acute kidney injury after TURP. What were serum electrolytes levels? What was the ABG report?

Why was frusemide given? A detailed account of postoperative labs including CBC, BMP, and culture if performed will be useful. Was there any hydronephrosis? Any element of resection close to ureteric orifice causing a transient bilateral ureteric obstruction? It will be beneficial to the reader to have a chart of pre and post-operative biochemical investigations. Was the patient on any nephrotoxic medications?

Acute pancreatitis can occur in post-operative cases and due to any metabolic disorders. (PONKA JL, LANDRUM SE, CHAIKOF L. Acute Pancreatitis in the Postoperative Patient. Arch Surg. 1961;83(3):475-490.) $)^{1}$ How can authors be so sure that frusemide is the potential cause? It appears multifactorial in the present case.

\section{References}

1. PONKA JL, LANDRUM SE, CHAIKOF L: Acute pancreatitis in the postoperative patient.Arch Surg. 1961; 83: 475-90 PubMed Abstract | Publisher Full Text

Is the background of the case's history and progression described in sufficient detail? No

Are enough details provided of any physical examination and diagnostic tests, treatment given and outcomes?

Partly 
Is sufficient discussion included of the importance of the findings and their relevance to future understanding of disease processes, diagnosis or treatment?

Partly

Is the case presented with sufficient detail to be useful for other practitioners?

No

Competing Interests: No competing interests were disclosed.

Reviewer Expertise: endourological management of kidney stone and enlarged prostate

I confirm that I have read this submission and believe that I have an appropriate level of expertise to state that I do not consider it to be of an acceptable scientific standard, for reasons outlined above.

The benefits of publishing with F1000Research:

- Your article is published within days, with no editorial bias

- You can publish traditional articles, null/negative results, case reports, data notes and more

- The peer review process is transparent and collaborative

- Your article is indexed in PubMed after passing peer review

- Dedicated customer support at every stage

For pre-submission enquiries, contact research@f1000.com 